\title{
Private Tutoring Boom in Nigeria: An Investigation into the Emerging but Controversial Learning Space
}

\author{
Oyewusi, Lawunmi Molara \\ Department of Educational Technology Obafemi Awolowo University, Ile-Ife. \\ oyewusilawunmi@yahoo.com \\ Orolade, Kayode Stephen \\ Department of Educational Technology Obafemi Awolowo University, lle-lfe. \\ kayodeorolade@gmail.com
}

\section{Doi:10.5901/jesr.2014.v4n6p271}

\section{Abstract}

The emergence of the traditional learning space called 'lesson' in Nigeria has indicted not only the government but also the teachers. More indicted are the parents who appear to find themselves between the anvil and hammer. Going through literature, the same space called 'lesson' in Nigeria is called 'shadow education' in some countries while some refer to the arrangement as 'private tutoring'. Irrespective of the name given to it, the arrangement is gaining ground to the extent that students of nowadays find it difficult to engage in independent study. However, the 'permissiveness' found at the spaces where private tutoring is taken place has given way to students' engagement with some mobile technologies - transiting into mobile learning environments. This paper will give an overview of Private Tutoring in Nigeria and discuss its reach and patterns. It will investigate some rationale behind widespread adoption of the innovation. Since the study exposes how the traditional independent study is giving way to ubiquitous learning, it will conclude with a discussion of the future of the learning space in question.

Keywords: Lesson, summer school, private tutoring, remedial education, coaching, learning spaces tutorial.

\section{Introduction}

The word 'lesson or 'coaching' is no longer new to any household in Nigeria. It has even become a major component of educational sector. Although it has taken a new dimension (now expanded) and also have been called 'remedial' and 'tutorial' by both organizers and the participants in the programme who are mainly students preparing for examinations. This same arrangement is called 'evening classes' indicating the time the participants (students) partake in it which mostly happen to be right after the regular school hours. 'Summer school' is another common name used in describing the programme suggesting that it occurs during the long vacation period from school. From the look of things, the timing and the nature dictates the name. The recent name given in literature as a major umbrella is 'private tutoring' because it is a private arrangement taken place after the regular school and for a fee.

\subsection{Prior to private tutoring}

Its history from findings cannot be up to a hundred years in Nigeria. This is because many living adults who are retired professors and old time administrators confessed that private tutoring was not in existence during their youthful days. What was it like then during their time? How were their evenings utilized?. From personal interviews conducted, independent study (without a tutor) to prepare for examinations was very common during their time. There was selfconfidence in academics and some of their evenings were used memorizing the necessary part of learning. In their words, they do not have to fret because of any examination. In addition, there was more and closer association with their parents, especially their mother. They unconsciously learn trade and hobbies, washing, cooking and social home behaviour after school. Some of them hawk to help their parents financially. Not going for lessons in the evenings has helped them to organize sports training in the evenings. As for their holidays, travelling was essential part of their education. Many of them travel visiting uncles, aunties and family friends. All work without play makes Jack a dull boy This adage was recognized during their time and they kept to it. 


\subsection{Present state of private tutoring}

In this day and age, both evening and holiday periods have been 'hijacked' because of students' involvement in one private tutoring or the other. Some of the tutors themselves are parents who are trying to make additional income to their regular salaries. They no longer have time to themselves. This is probably what Oyewusi (1990) meant when he lamented that the parents' love for their children have taken a dangerous dimension. Foodun (2002) defined private tutoring as the extra coaching in academic and examinable subjects that is given to the students outside school hours for remuneration. The spaces for coaching can be in the teacher's home, pupils' homes or a school premises while many private tutoring centers nowadays occupy their own buildings.

The timing could be after school, weekends or during holidays. It can be organized by the student's parent, by teachers who are genuinely concerned or otherwise by the school or by private tutoring centers or organizers. Private tutoring today is available for almost all subjects that are taught and assessed at the regular school. The most popular subjects are English and Mathematics because they are made compulsory at all entrance examinations (from primary to university). A student can later include subjects related to his or her intended or chosen career.

\subsection{Who are the tutors in private tutoring centres?}

The tutors are of various categories. They can be full-time or part-time teachers in the learning spaces. They can sometimes be the tutee's teachers in the regular classroom. Most times when the private centers are considering low remuneration, they may use National Youth Service Corps (N.Y.S.C) members or university students. But most of the time, they have fixed remuneration for all teachers irrespective of their cadres. Gordon (2003) has this to say about the teachers:

\footnotetext{
"Interviews with hundreds of these teachers revealed that the majority do not see themselves as homework helpers or test-preparers, but rather as short-term 'learning detectives', therapists and mentors. The best tutors are good diagnostician who discovers the causes of a student's inability to learn in the classroom" (pg 457).
}

The above quotation depicts what some of the teachers are to the students they teach for remuneration. Private fee is expensive as its organizers and parents are ready to pay such amount as long as they can have their children there. The organizers are scattered all over the cities and towns within the country. Without mincing words, there should be over two million private tutoring centres all over Nigeria without counting what goes on in individual homes. And as at the time of this study, many more are still being planned. No matter what, it is the concern for the education of the young ones who will eventually take over from the adults who have motivated this study.

\subsection{Rationale behind the boom}

The instrument for gathering information for this segment include structured interview among teachers and parents. A lot of reasons have been adduced to be responsible for the boom of private tutoring centres in Nigeria and these have been identified as follows:

\subsubsection{Parental engagement}

One common fact about most parents who are civil servants in Nigeria is that they are always pre-occupied. They resume work in the mornings around $7.30 \mathrm{a} . \mathrm{m}$. and close around $4.30 \mathrm{p.m}$. in the evenings. This goes contrary with the children (both in the primary and the secondary) because they will always leave school around 1.00 p.m. or 2.00 p.m. in the afternoons. In state capitals and cities like Lagos, Abuja and Port-Hacourt, closing time for workers may be longer than 4.00 p.m. because of traffic hold-up and some may sometimes get home around 7.00 p.m. or 8.00 p.m. The issue of where the children would be for the period of four to six hours before the parents' arrival from work has precipitated the need for daily lessons. The children therefore will move from their regular school to the privately arranged tutorial centre to stay until their parents come back from their work places. Some parents feel inadequate to assist their children with various assignments given to them at school. A private tutor may be otherwise needed to assist with the homework or assignment. 


\subsubsection{Student or pupil's deficiency}

Some students are academically weak such that they do not gain much from the classroom. The parents, especially the enlightened ones as a result of this may seek the help of a private tutor whom they believe will give a sort of academic assistance to the pupil or the student. Besides, a child may be otherwise be brilliant, but may be preparing for specialized examinations. Such a child may need the services of specialized tutors. At the primary school level, a child wanting to sit for the National Common Entrance may need coaching in the areas of Verbal Aptitude Test (English) and Quantitative Aptitude Test (Mathematics). At the secondary school level, a child may want to sit for either Junior or Senior W.A.E.C. (West African Examinations Council) examination. It may be UTME (University Tertiary Matriculation Examinations) which will be used to admit a child into a university. All these examinations are very competitive and most educated parents consider it a shame if their ward cannot meet up to expectation. This, to some, requires tutoring a child specially and seeking outside help.

\subsubsection{Poor remuneration of the teachers}

Teachers' poor remuneration is also a significant reason for the widespread nature. It has always been the belief of the Nigerians that the 'reward of a teacher is in heaven'. Today, because of their involvement in private tutoring where they are receiving untaxed income they have always replied that their reward is now on earth. They see the situations explained above as an opportunity for them. When they teach a child or a group of children and they perform well in examinations, the teacher who is been commended may see such commendation as a license to start his/her private tutoring centre.

\subsubsection{Inability of the regular school}

Another reason for the boom is the inability of the school. The reason while a child would leave a public school for a private school is because of what the parents believe is the inability of the public school. But today, even students from private schools are enrolled in private tutoring. The reason for this is not far-fetched; many parents have found out that some teachers reserve the energy they could have used in the regular classroom for the private lesson period.

\subsubsection{Peer group pressure}

The last reason identified as responsible for the widespread nature of private tutoring is peer group pressure. Many of the students in Nigerian secondary schools today who are in private tutoring centres got to the learning space through their friends. The 'make believe' is that locked doors always get opened for admissions when you attend lesson or a private tutoring centre. Foondun (2002) quoting Ward (1941) has this to say on the issue raised:

Private coaching, I am told is almost universal among the boys, and competition keeps it so; for if one boy has a private coach, his rival must have one too ... (page 39).

\subsection{The Controversy}

Like the title of the study, the learning space in question is controversial. And up till date, the controversy still remains unsolvable. Groups of people speak for and against, but no concrete stand has been made. Many parents still insist that their children would not have private tutors and such children still find it easy to compete well in the competitive world. This made one to conclude that the issue of private tutoring is optional.

Those who speak in support sees private tutoring as a welcome opportunity to increase the income of formal school teachers whose salaries have been eroded for decades. Demand and supply factors to them are thus reinforcing each other, creating a real market for students coaching. Teachers therefore see it as a means of additional untaxed income. Some parents see tutoring as a road to their children's social and economic advancement. To them, it is a 'private contractual arrangement between teachers and parents, whose right to seek additional assistance for the education of their own children is at their own expense and as such cannot be questioned'. With this issue raised, attempt to eradicate private tutoring might be a little bit difficult.

If one will have to weigh things, the points raised against private tutoring seem to be louder and touchy. Farah (2011) for example argued that too many hours spent studying can infringe on the leisure time of children, and that this 
may have negative effects on their mental, social and physical well-being. This has made people to see the arrangement as a cankerworm and an unprofitable venture. Some educators argued that private tutoring leaves the children no time to study on their own. Independent study was very common in the past, but today's children can hardly read on their own. Lots of research have been carried out to determine whether tutoring has positive impact on students' academic performance. Many also argued that private tutoring deepens the social inequalities between the rich and the poor. To them, the huge money paid in some private tutoring centres can be a financial barrier for poor families.

Furthermore, those who believe in tradition had proposed a proscription. They argued that the necessary culture that were imparted in the past most especially to the girls have been neglected because they were engaged with schoolwork all through. Media have been used to attack the arrangement in some countries but didn't put a stop to it because the points raised on both sides are weighty. The study feels strongly that decisions should be left with the policy-makers and educators. They should be able to determine what fees to be levied and the extent of practice. The parents too should be enlightened as regards the pros and cons of the arrangement as this will make them to also take a decision.

\subsection{Space for New Technologies}

The emerging private tutoring centres despite all their shortcomings have started adding another feather to their caps by providing environment for embracing Information and Communication Technology (ICT). This is due to their permissiveness; they are the new homes for all the technologies that are banned and prohibited in the regular schools (smartphones, laptops, ipad, ipod, mp3 and many others). The reason for this is not far-fetched because the centres contain students from rich backgrounds as well as the private tutoring organizers need their money for financial return. They would not want to drive the students away; so, they must accommodate the students and their technological devices. With this new development, what we have now is a crop of students going in and out of private tutorial centres interacting and learning with technology. Initially, the intention might be to show off or create a sort of luxury, but as time goes on, the socio-economic inequity is bridged as those who do not have these technologies strive to have or probably share with those that have. In all of these, we see a future. We foresee centre for developing collaborative learning with the use of technology, a centre where different educational approaches will emerge. No wonder, Thackara (2005) posited:

\footnotetext{
'... new technologies call for new geographies of learning that capture the interrelatedness between student learning, times, places, topics and technologies.'
}

\subsection{The Future of Private Tutoring Centres}

This year (2014) University Tertiary Matriculation Examinations (UTME) will be computer based. This is the first time that a major examination will be taken that form in Nigeria, at least at the post secondary school level. Post-UTME (University Tertiary Matriculation Examinations) into some universities also has been computer-based. This development would not be strange to any student who had passed through private tutoring centres. This study is of the belief that the private tutoring centres of the future, if they remove exorbitant fees and remain focused will be training ground for technological development.

There used to be a tutorial college in Osun State of Nigeria grooming students for future examinations. It grew from a tutorial college to a polytechnic and from a polytechnic to a university. If truly there is a National Accreditation Body for the establishment of Polytechnics and Universities and who are honest to defend the assignment, then, we should expect more of universities in the country. Some organizers of private tutoring centres are actually working round the clock, truthful and making sure that the reputation given to their centre is not ill-gotten. With such in the country, we see future universities who will cater for large numbers of applicants.

\section{References}

Farah, S. (2011). Private Tutoring Trends in the UAE, Dubai School of Government Policy Brief. No. 26, 1-8.

Foondun, A.R. (2002). The issue of private tuition: An Analysis of the Practice in Mauritius and - Selected South-East Asian Countries. International Review of Education. Vol. 48. (6): 485-515

Gordon, E.E. (2003). Looking Beyond the stereo types: Ensuring the True Potential of Tutoring. Vol. 84(6) 456-459.

Oyewusi, J.A. (1990). "Lesson Organization in Nigerian Schools." Unpublished Paper.

Thackara, J. (2005). In the Bubble: Designing in a complex world. Cambridge.M.A MIT Press

Ward, W.E.F. (1941). Report on Education in Mautitius. 